\title{
Avalokiteśvara in Tibetan Buddhist Art of the Later Spread (Tib. phyi dar) of the Dharma. Image Classification Proposal, Part 2
}

\author{
Joanna GRelA
}

\begin{abstract}
According to traditional Buddhist narratives and popular beliefs, Tibetans are a people chosen by Avalokiteśvara. Therefore, his worship and multitude, as well as diversity of his images, are quite common both in temples and public areas. Unlike the widespread analyses where the Bodhisattva has been treated as a peaceful tutelary deity, and classifications of its images have been based on morphological features, or artistic styles and techniques, this paper proposes another approach by grounding images in Tantric Buddhism models used locally, e.g. outer, inner and secret forms of the Three Jewels or the Three Refuges, popular in Tantric Buddhism. The second part of this paper focuses on images of Avalokiteśvara as a meditational deity and a Dharma protector, which corresponds to the last two out of the three inner aspects of the Three Jewels. Using the method developed by Erwin Panofsky and the analysis of primary Tibetan text are partly used as convenient tools for the description and exegesis of images.
\end{abstract}

KEYwords: Avalokiteśvara images, Erwin Panfosky, Six-Armed Mahakala, Three Jewels, Three Roots

JoAnNA Grela a Tibetologist, professor at the Jagiellonian University, employed at the Centre for Comparative Studies of Civilisations. Her research interests include Tibetan traditions and contemporary Buddhist cultures.

(iD https://orcid.org/0000-0001-7696-5296

E-MAIL: j.grela@uj.edu.pl 


\section{Avalokiteśvara as a meditational deity and a Dharma protector}

The iconological exegesis, anchored in the concept of the three poisons of an ordinary mind, classify anthropomorphic figures of Tibetan Buddhism deities in the following way:

- Peaceful, gentle-looking deities (Tib. zhi ba); their role is to facilitate the transformation of ignorance, bewilderment (Skt. moha; Tib. gti mug);

- Lustful-looking deities (Tib. chags pa), depicted as a couple in a sexual act or a single deity, often in red; they are supposed to transform desire and attachment (Skt. rāga; Tib. 'dod chags) into bliss;

- Fierce-looking, wrathful deities (Tib. kro bo, drag po); they are supposed to lead to the transformation of anger and hate (Skt. dveșa; Tib. zhe sdang) into clarity of mind (Namkai Norbu 1989, 22).

Avalokiteśvara appears in the Tibetan art in all of the above forms, where the most popular are the depictions of the first type, usually as a white, 2-, 4-, or 1000-armed male form. An example of the second group of depictions can be a red sitting Gyalwa Gyamtso (Tib. rgyal ba rgya 'mtsho) - alone, e.g., with one face and four arms or in sexual union with a female partner. This form was introduced into the Tibetan pantheon from India by Rechung Dorje Dragpa (ras chung rdo rje grags pa, 1083/4-1161), first to the Kagyu (bka' rgyud) school, before it was popularised in other schools. The SixArmed Mahākāla (Skt. sadbhūja mahākāla; Tib. mgon po phyag drug pa) is considered, according to the texts of the Shangpa Kagyu (shangs pa bka' rgyud) school, to be a wrathful form of Avalokiteśvara and also a Dharma Protector. The school founder, Khyungpo Naldjor (khyung po rnal 'byor; $11^{\text {th }}$ century), introduced this meditational form to Tibet, in a dozen figures, with different colours and attributes.

The Six-Armed Mahākāla is considered by the adepts of this school as completely encompassing the Three Roots into one, i.e. being a teacher (lama), meditational deity (yidam) and Dharma protector, where each of these roles has its iconographic form, its sādhanā or its part. ${ }^{1}$ An important iconographic detail is the Six-Armed Mahākāla's legs position. Only in the Shangpa Kagyu school, the deity is depicted as standing on almost straight legs, in a jumping-ready position (Photo 8), with legs slightly apart. In other schools, particularly in Gelug (dge lugs), where

1 More on the subject, see: Grela 2005, 179-189. 
he is also popular, the deity is standing on one leg in a dancing pose with the right leg more (Photo 10) or less (Photo 9) bent at the knee, with legs wide apart.

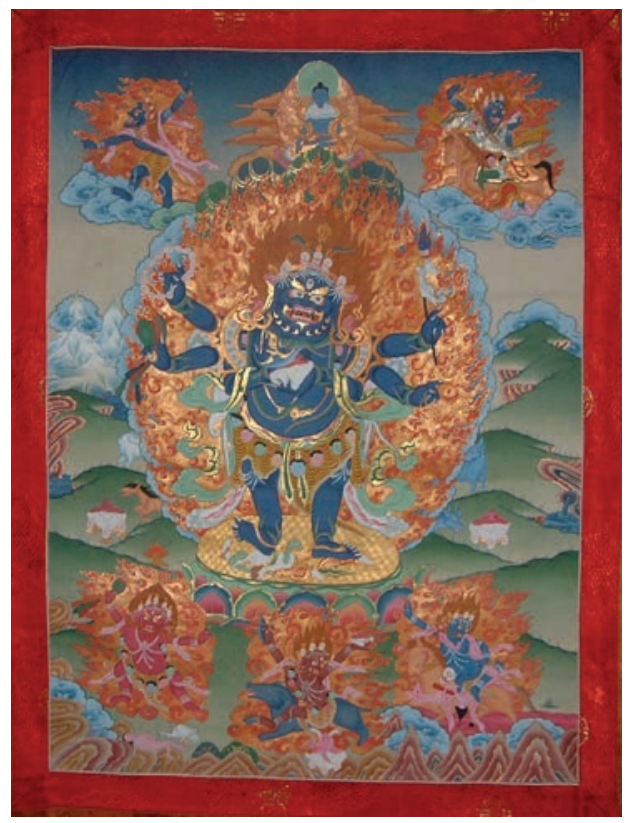

Photo 8. Six-Armed Mahākāla with his retinue of deities. $20^{\text {th }}$ century. Photo by Joanna Grela, private collection.

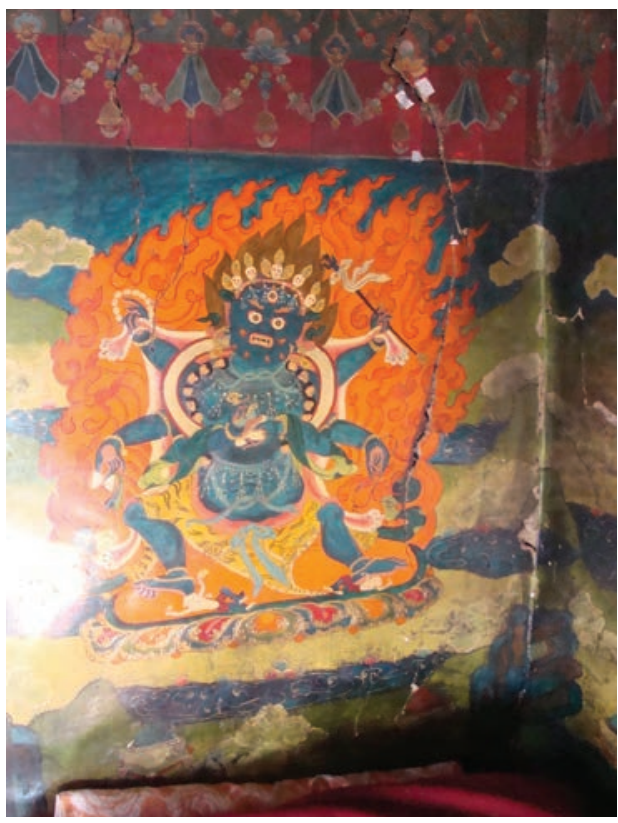

Photo 9. Six-Armed Mahākāla, Yumbu Lagang. Photo by Joanna Grela.

Due to the fact, that Avalokiteśvara's images were created locally not to inspire aesthetic but religious experiences, their description and analysis should, in my opinion, consider not only the emic categories introduced above, but also the broadest possible cultural, religious and semantic context, in order for the vision conveyed by a given image to be better understood. To do so, I propose using the classical method by Erwin Panofsky (1955, 26-41), first created to analyse works of European culture, but is universally useful and applicable. This method comprises: (1) pre-iconographic description, (2) iconographic analysis, and (3) iconological interpretation, where each one reveals subsequent layers of the image's meaning.

(1) The description step is supposed to uncover the so-called primary or natural subject matter. This stratum consists of a simple perception of the work's form. Since I am using this method only demonstratively, in this and 
following points, I will not present a full description of the Six-Armed Mahākāla image. In the above pictures, based on the lines, colours and shapes, we can among other details identify an anthropomorphic standing dark blue male figure with six arms. This is an example of the so-called objective

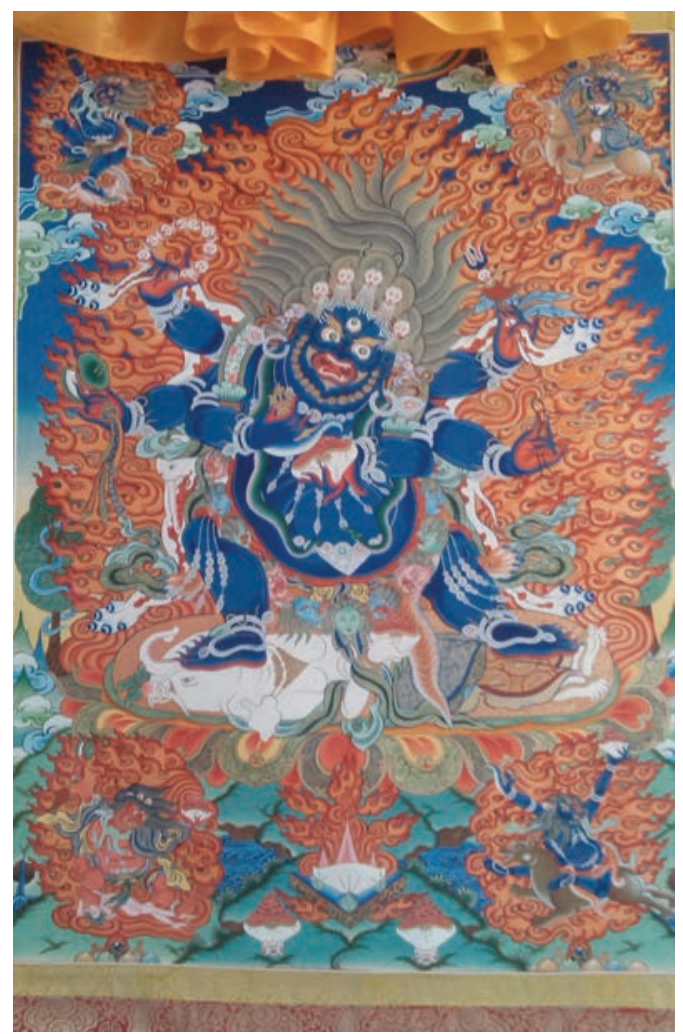

Photo 10. Six-Armed Mahākāla, private collection from Wutong village, Rebgong (Chin. Tongren county). $21^{\text {st }}$ century. Photo by Joanna Grela. meaning. The first step also includes revealing the so-called expressive meaning, i.e., the one requiring reading the emotional content or mood, through a configuration of objects, gestures, facial expressions, etc. The described six-armed figure surrounded by smaller figures are shown in a flaming aureole, with skulls on their heads, with protruding fangs and other attributes of the sort. Based on that the abstract meaning (the mood) might be read as astonishing. A result of pre-iconographic analysis is recognising all motifs and basic meanings present in the image. It can be identified universally and doesn't require any added specific cultural knowledge.

(2) The second step in Panofsky's method, i.e., the iconographic analysis, consists of reading the secondary or conventional subject matter: decoding symbols, cultural motifs, which determine the subject matter of the work. In this case, cultural knowledge, as well as familiarity of motifs and subjects, are necessary. The iconographic analysis being culturally conditioned has a limiting character since it reveals a meaning arising from the knowledge acquired within a given culture or tradition and is only clear within that cultural context. For example, a person well versed in Buddhist and Tibetan culture will recognise the subject of the images presented above as a depiction of a Dharma Protector, the wrathful form of Avalokiteśvara. Apart 
from defining the theme of the image, this step makes it possible to decode the symbolism of the motifs. For example:

- The dark blue colour of the main form can be interpreted as a symbol of an unchanging insight into the nature of reality; ${ }^{2}$

- Sandal tree, against which the figure is propped (with its treetop visible in Photo 8, above aureole of flames) - being a support to his followers;

- Flaming aureole - destroying the ignorance (Skt. avidyā; Tib. ma rig pa);

- A crown of five dry human skulls - obtaining the qualities of five Buddha families, which are a result of transforming five poisons of the mind;

- One face - recognising a single nature of all phenomena;

- Three eyes - knowing three times;

- Four fangs - taming the four demons, i.e., attachment to: (1) sensual phenomena, (2) thoughts, emotions, (3) euphoria, rooted in religious experiences, and (4) "self" as an independent entity;

- Six arms - leading beings out of the six realms of samsāra.

wrathful form of Avalokiteśvara holds in his hands respectively:

- A garland (Skt. mālā; Tib. 'phreng ba) of skulls, symbolising a tireless activity of helping others;

- A small two-headed drum (Skt. ḍāmaru) - power over ḍākinīs;

- A skull cup (Skt. kapāla; Tib. thod phur) filled with flesh and blood of enemies - the death of an enemy, i.e. elimination of attachment to "self" and the end of samsāra;

- A trident (triśūla; mdung rtse gsum pa) - power over the three realms of samsāra (Skt. triloka): the desire, form, and formless one;

- Black noose - neutralising obstacles and demons, as well as taming those, who break Tantric vows.

Other significant motifs, present in this form of Avalokiteśvara, are also:

- Elephant skin thrown over the back symbolising conquering pride;

- Tigerskin around the hips - conquering desire; a green silk scarf supporting the skin - using sensual pleasures on the spiritual path;

- Snake accessories - subjugating nāgas;

- A necklace of fifty one blood-dripping heads - purifying fifty one main mental states (Skt. caitta; Tib. sems byung);

2 An interpretation carried out based on the main Tibetan commentary of the Shangpa Kagyu school: Myur mdzad... 1982, 400-402; and Tcheuky Sengué 2002, 37-74. 
- Bone accessories symbolise six pāramitās: a circle in the hair - concentration, earrings - patience, bracelets on wrists and ankles - morality, a necklace - generosity, an apron - perseverance, a breast-plate - wisdom;

- Two legs - a symbol of skilful means (upāya; thabs) and wisdom (prajñā; shes rab), standing position - non-abiding in the extremes of neither saṃsāra nor nirvāna.

(3) Panofsky's third step is iconological interpretation, consisting of reading the intrinsic meaning or content. At this stage, the image is not treated as an isolated incident, but as the product of an entire environment. The researcher looks for the image and image-pattern origin, its correlation with philosophical, religious, literary, cultural, or political ideas of a given era, tracks mythological signs, identifying and investigating the broadest context possible. The third step requires an expert level and is a virtually endless task. At this stage of the analysis, one can, for instance, refer to a legend of a yogi Sāvaripa ( $10^{\text {th }} / 11^{\text {th }}$ century), who, according to the Mahākāla Tantra (Dpal nag po chen po'i rgyud... 1982, 24-26), was the first to have a vision of this form of Avalokiteśvara, when doing Tantric practices in the cemetery called the Cool Grove (śitavana; bsil ba'i tshal), near today’s Bodh Gaya. Legend says that he heard noises of a drum and bells, after which he saw an awesome figure engulfed in flames. Terrified Sāvaripa would raise his eyes little by little, and therefore (although traditionally the deities of the Tibetan pantheon are described from head to foot) to commemorate this event, the wrathful form of Avalokiteśvara is described in the opposite direction: from the feet up. This information includes a clue about the previous steps, through which - to respect and be in line with tradition - one should correct the order of description and analysis.

The Great Black One Tantra in eight chapters links the Six-Armed Mahākalā with a well-known story of Avalokiteśvara, who promised Amitābha Buddha to work tirelessly to free all sentient beings from samsāra. He also pledged that he would sooner break into pieces than give up helping others. However, when he realised that despite all the hard work the number of suffering beings was not decreasing, he lost faith in the purposefulness of his actions and thus broke his vow. When he burst into pieces, Amitābha came to the rescue, put him back together and gifted with a thousand heads and arms to give him more opportunities to help. Despite multiplied powers, Avalokiteśvara still apparently felt depressed, unsure of how to fulfil his mission. Legend says that he then realised that if he additionally had a fierce, fast, and powerful form, he could do his job much more effectively. Then from his heart emanated 
a dark blue hūm syllable, which transformed into a Six-Armed Mahākalā. It is said that the Earth shook six times then and Amitābha Buddha with countless other Buddhas declared that this new form of Avalokiteśvara will from then on be an invincible Dharma protector and will obtain the power to grant all wishes. ${ }^{3}$

Khyungpo Naldjor, who implanted this form of Avalokiteśvara and initiated its worship in Tibet, according to religious biographies ${ }^{4}$ was born in a family of Bon practitioners and became fluent in this tradition. In Tibet, he also studied the so-called great perfection (Tib. rdzogs chen), becoming a master of this line. Still, he kept on searching for a more comprehensive and universal Dharma, so he travelled to India several times, to listen to teachings of many gurus. At the end of his second visit from Maitrīpa (c. 1007-1085) he received the sādhanā of the Six-Armed Mahākalā, presented to him as a universal deity, personifying all the lamas, yidams, d̦ākinīs and Dharma protectors. Due to the fact that the text of this sādhanā makes it possible to see in the analysed image with more detail and place iconographic details in a wider context, below, I present an excerpt of a $19^{\text {th }}$ century supplement to the canonical text, describing the visualisation of the Six-Armed Mahākalā and his retinue (Kongs sprul blo gros mtha' yas 1982, 277-288):

From the emptiness domain a hüm syllable appears and transforms into a protective circle, containing [eight] large, terrifying cemeteries. In the middle, from the pam syllable, a multicoloured lotus appears, [on it] from the ram [syllable] a Sun disc appears, on which there is a white gam syllable, transforming into light. From it white Vinayāka ${ }^{5}$ appears with a head of an elephant and three eyes. In his right hand he's holding a horseradish - the essence of earth - with leaves; he is bringing it to his mouth. In his left

3 Dpal nag po chen po'i rgyud le'u brgyad pa 1982, 23. In later literature on the subject, e.g., a text from $16^{\text {th }}-17^{\text {th }}$ century, see: Tāranātha $1982,722-723$, other elements are added to the legend: Avalokiteśvara, put back together, decided to undertake a threefold activity: liberating beings from the bardo, i.e., a state between death and rebirth; helping the poor; freeing them from suffering. After seven days from his heart, the hüm syllable emanated. The Buddhas then foretold that the Six-Armed one will have the power of wisdom dākinīs and the Lord of Death (Skt. Yamāntaka), whereas demons, yakṣas, rākṣasas, etc., will be subordinate to him. The Buddhas were to nominate him the Dharma protector in the Buddhas' pure realms.

4 Hagiography (1) Bla ma khyung po rnal 'byor gyi rnam thar zur tsam; (2) a prayer to hagiography: Karma ngag dbang yon tan rgya mtsho; (3) a collection of the so-called songs of realisation Dpal ldan shangs pa bka' brgyud kyi do ha....

5 Both the name and the head of an elephant might evoke an association with the Hindu Ganeśa, however, according to commentaries Vinayāka is considered a separate form, a ruler of demons distracting from the religious practices (Skt. vighna, Tib. bgegs). 
hand he is holding a jewels spewing mongoose. Vinayāka is lying, adorned in silks and jewels, and a stream of gems is flying from his mouth, nose and all skin pores. Above him, from hūm a burning vajra-knife [Skt. kartika; Tib. gri gug] appears with a dark blue hūm syllable. The syllable emanates light which eliminates enemies, difficulties and any negative forces; it is a gift for the Noble Ones, it accomplishes the purpose of the beings. When the light returns, the knife turns into an instantly acting six-hand wisdom protector, who fulfils all hopes and wishes of beings.

His body is completely dark, like the clouds of the end of times. He has one face, six arms, three red, protruding eyes, a fierce gaze. His wide open mouth reveals fangs and a rolled tongue. The six-armed one is laughing sharply and has a ferocious look. Dark yellow hair on his head, chin and eyebrows sticks out. He has a cinnabar dot on his forehead, and his head is crowned by the Aksobhya Buddha.

In his first right hand he is holding a vajra-knife, and in his first left hand, by the heart, he is holding a kapāla filled with blood and flesh of the enemies and harmful beings. In the middle right hand he is holding a mālā of dry skulls and the bottom one is rhythmically shaking a d̦āmaru. The other left hands are holding a trident and a black noose, respectively. Two legs in a balanced position control the three realms and crush the king of obstacles, Vinayāka. The upper part of the body [of the Six-Armed one] is covered in elephant skin, his hips are wrapped in tiger skin, belted by green silk; he is adorned by accessories made from large snakes: his hair is tied with blue snakes, in his ears - as earrings - he has red snakes, his arm bands are multicolour snakes, necklaces are white snakes, wrist bracelets are yellow snakes, a long necklace - are green snakes, ankle bracelets and the belt are white snakes. He has multiple bells attached to his hands and legs. He is corpulent, with a protruding belly and short arms and legs. He is emanating endless glow. He's wearing a crown of five dry human skulls, he is wearing a necklace of fifty bleeding heads, he is adorned with six bone accessories and a crown of jewels.

His terrifying roar - ha ha hüm hüm phat phat - resembles thunder destroying demons, enemies and everything that's harmful. He is standing propped against a sandal tree trunk, engulfed by blazing wisdom fire, similar to the fire of the end of a kalpa.

To his left, in the middle of a stormy ocean of blood clots, created from the syllable bhyo is Palden Lhamo [Skt. śrī devī, Tib. dpal ldan lha mo], ruler of the realm of desire - black and very wrathful. She is holding five magical 
weapons: she is brandishing a demon black mace, which she is holding in her right hand; in the left hand she has a bag of diseases; a white and black dice are attached in the front of the saddle; in the north a red tablet; a spool of threads in the back of the saddle. She has three eyes, bare fangs and an angry face. Her hair is tied in a bun at the top of her head with a peacock feather sticking out. The sun is rising from her navel and the moon from the top of her head. She's riding a mule. The front of the saddle is rākșasa's top jaw, the back is the bottom jaw. Her upper body is covered with elephant skin, the lower with cow skin; she's wearing black silks and a skirt made from yak's hair. She is adorned with accessories made of bones, a crown of human skulls and a necklace. In her right ear she has an earring of a venomous snake, and a tiger earring in the left one. She is engulfed in fire and whirls of sand storms. She is surrounded by flesh eating demons and thousands of mamos and dākinīs.

In front of the main one [i.e. the Six-Armed one] from syllable kșim yakșa Ks setrapāla appears - dark blue with wide open mouth and bare fangs, inspiring terror in enemies. From his nostrils the wind blows as strong as the one at the end of a kalpa. [Kșetrapāla] brandishes a knife held in his right hand, which terrifies the devas and asuras. He's holding a kapāla filled with blood in his left hand. He is riding a wild bear; he is surrounded by an assembly of evil spirits and yaksas.

To the right, from the hüm syllable, a powerful Jinamița appears - dark red, looking like a wrathful rākșasa. A fountain of poison and blood spurts from his mouth. With his right hand he is violently shaking a dāmaru, and with his left he is making a tarjan̄ mudrā blazing with flames. He is surrounded by planets and hosts of rākșasas.

Behind [the Six-Armed one] from the tam syllable a yamā Țakkirāja appears - black, hungry for human flesh and blood. He is throwing a lasso of intestines at enemies, and with his left hand he's making a tarjani mudrā directed at yaksas. He is surrounded by yamās.

The last three figures are adorned with bone accessories and are wearing skirts made from tiger skin.

To the left [of the Six-Armed one] from the hüm syllable a great ruler of demons, Takșad appears, black like the clouds from the end of a kalpa. He is holding a lance with red points of a trident at the end, with which he pierces the hearts of the enemies. With his left hand he is lifting a blood-filled kapāla to his mouth. He is biting his lower lip with upper teeth, revealing fangs. He is wearing a long coat of black silk, trimmed with dark swastikas, 
high Mongolian boots and a golden belt. He is riding a demonic black horse with white fetter bones. He is surrounded by an innumerable army of devas and demons.

All four of them have three red, protruding eyes, menacingly looking at the enemies and the beings causing trouble. All are bearing fangs, are restless and angry. Their fill other with disgust and great fear. Their hair, eyebrows

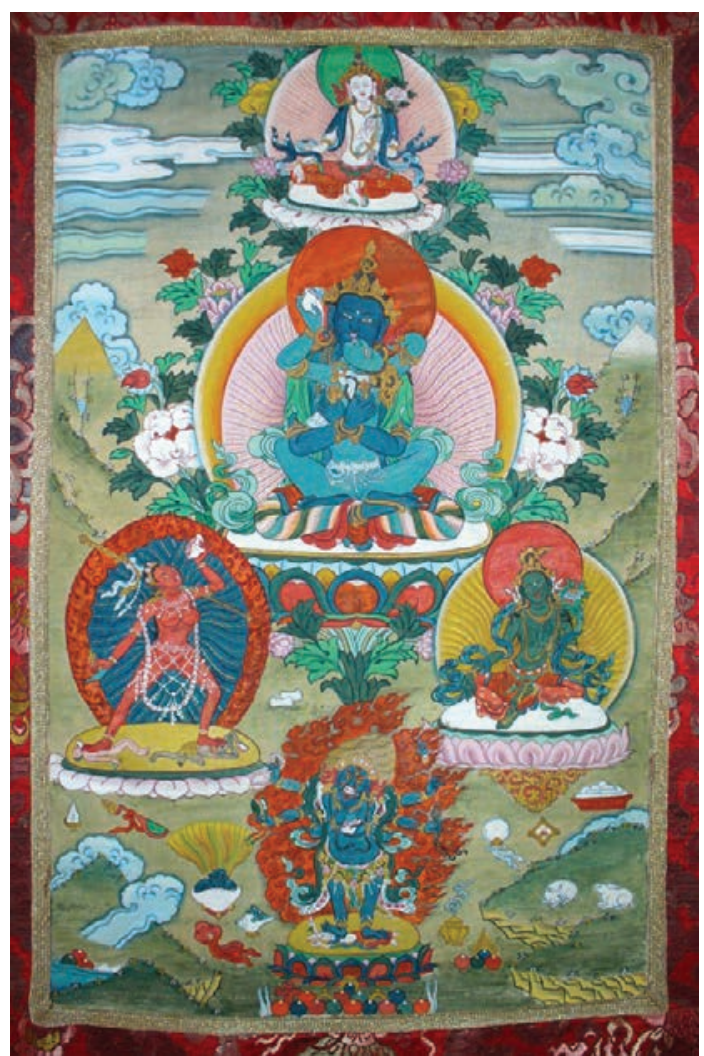

Photo 11. Four Deities in one Mandala. Source: https://paldenshangpa.org/combinedaccomplishment-of-the-four-deities-lha-chi-drildroup/4-deities-2/ and beards are fawn-coloured and on fire. They are wearing crowns of dry skulls and long necklaces of bleeding human heads. They are abiding in the bull's eye, surrounded by a mass of crackling fire.

According to religious biographies (Dpal ye shes kyi mgon po phyag drug pa'i chos skor byung tshul... 1982, 732-734; Gzhon nu dpal 1996, 732) not much later Khyungpo Naldjor, already in Tibet, was visited by an Indian mahāsiddha Rāhula who gave him sādhanās of each of the above male forms of the immediate retinue, out of which only the sādhanā of Kșetrapāla survived till present time. The Tibetan guru was also supposed to obtain the transmission of the aspect called the "Combined Accomplishment [of the] Four Deities" (Tib. lha bzhi dril grub)

(Photo 11) with Vajradhāra and a consort in the centre of the mandala, Six-Armed Mahākalā in the front, Vajrayoginī on the right, Avalokiteśvara behind, and Green Tāra on the left.

Mahāsiddha Rāhula was also supposed to pass to the Khyungpo Naldjor the sādhanā and instruction to the white aspect of the Six-Armed Mahākalā, who was to guarantee wealth to the adepts. The Sanskrit name of this figure is 
an oxymoron: Sïtamahākāla literally means "White Great Black." The Tibetan name - Gonkar (mgon dkar), meaning the White Protector - resolves this paradox. The deity is also called Mahākalā (or the Protector) Wishfulfiling Gem (Skt. mahākālacintāmaṇi; Tib. mgon po yid bzhin nor bu), which is connected to the jewel held in his right hand at the level of his heart. According to Indian mythology, the jewel grants the wishes of those who rub it, and in Buddhism, it symbolises an enlightened mind - the source of everything. The other attributes symbolising wealth is a skull cup in the left hand with the nectar of long life and a vessel filled with jewels. The other right hands are holding a vajra-knife and a small two-headed drum of acacia wood, while the left ones a trident and a noose - when an adept identifies with the deity (Tib. bdag bskyed), or an iron hook when the deity is visualised in front of the adept (mdun bskyed); that last representation is seen in most paintings and sculptures renderings (Photo 12). The symbolic meaning of the other attributes is the same as in the case of the main representation of the Six-Armed Mahākalā (Beer 2004, 82-83). It should be noted, that the Tibetan commentary clarifies, that the iron hook and the noose, used in India to tame elephants, in a general Buddhist context symbolising: the hook - the precision of understanding, insight, and the noose - the ability to remember and recall (Beer 2004), in the case of the colourful forms of Mahākalā are symbols of attracting propitiousness. The White Protector - one of the forms of Avalokiteśvara as Mahākalā - is outside the Shangpa Kagyu school, from which it was borrowed by other Tibetan schools, particularly popular in Mongolia and Buryatia.

Khyungpo Naldjor introduced the Six-Armed Mahākalā to Tibet in more than ten forms, differentiated by colours and attributes. Individual colours are attached to Tantric aspects of an enlightened being: the white form represents the body aspect of Avalokiteśvara-protector and accomplishing the Tantric pacifying activity (Skt. śānticāra, Tib. zhi ba). A wrathful aspect of speech is represented by the red form of the Six-Armed Mahākalā, The King of Power (Tib. dbang gi rgyal po), supposed to make it possible to control the three known realms from Buddhist cosmology: desire, form, and formless realms and is associated with the magnetising activity (Skt. vaśîkarana, Tib. dbang ba). The basic black or midnight blue form, described above, is considered to be the mind aspect. The yellow form - unusually - has three faces: the right one is white, the left one is red, and the middle one, yellow. It represents the qualities aspect, it's supposed to guarantee a long life, accumulate merit, deepen meditative insights and realisation, and accomplish increasing activity (pauștika, rgyas pa); he is called the Yellow Protector Developing Intellect (Tib. mgon ser blo 'phel). This form, in some hands, holds different attributes other than colour 


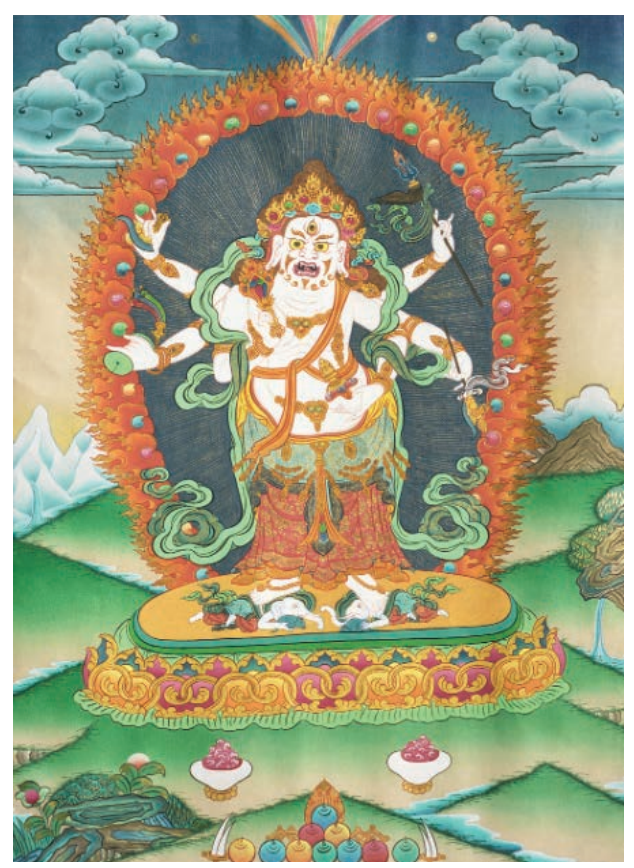

Photo 12. White Six-Armed Mahākalā. https://www.shangpafoundation.org/library/ artifact-page/white-protector/

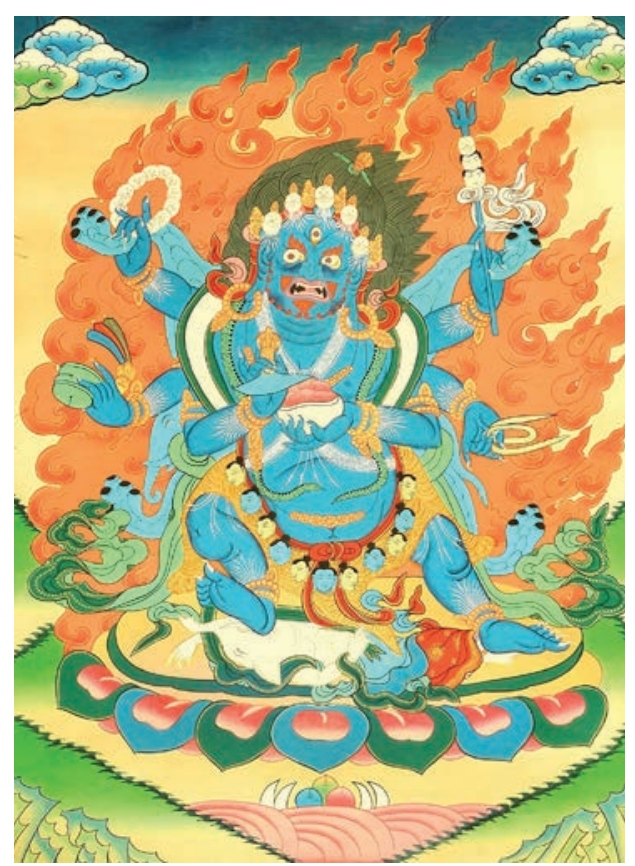

Photo 13. Green Six-Armed Mahākalā. https://www.amazon.co.uk/TibetanBuddhist-Six-Armed-Shadbhuja-Mahakala/ $\mathrm{dp} /$ BooMPGN $3 \mathrm{JW}$

forms. The Yellow Six-Armed Protector in his right hands holds a vajra-knife, a victory flag, and a mongoose, and in the left hands holds a skull cup, a blue lotus, and a snake. According to my research, Shangpa Kagyu commentaries to the sādhanā do not explain the symbolism of his attributes. The Green Form, Lord of Life Force (tshe bdag mgon po), personifies the activity aspect of Avalokiteśvara-Mahākalā; his domain is to remove obstacles, enemies, and unfavourable situations, i.e., the violent activity (abhicāra, drag po).

The phase of the iconological interpretation of Panofsky's method treats a painting as a summary of religious, historical and other stories, and is virtually endless. Turning to vernacular commentaries makes it possible to avoid automatically correlating popular motifs (e.g., from the context of the rich religious culture of India or one's own). For example, the third eye, which in India originally denoted the evil eye in demons (Maxwell 1997, 47), later in the context of Siva, meant the warmth of the Sun, which one could use to strike the enemy, even though it was something directed inwards 
(Maxwell 1997, 48). While three eyes of Śiva, according to Upanishads symbolised "the Sun, the Moon, and fire" (Bhasmajābala Upanișad 1), however, according to tradition, with the three eyes, Siva can also see the past, present, and future (Mahābhārata, 10, 1251) and that last correlation was widely adopted by Tibetan Buddhism.

\section{Conclusion}

The popularity of Avalokiteśvara, considered the Tibet's protector and a most popular meditational deity, translates into the commonness of his images. The brief analysis conducted from the iconographic and iconological perspective demonstrates a complex meaning and possible functions of the various images representing the Bodhisattva. The categories used in the article, which come directly from the researched culture, were employed to draw attention to a much larger number of his images, including his mantrā or his wrathful forms, and also group them in a way different from the one adopted by researchers. Avalokiteśvara has been traced as a universal figure, appearing and fitting into virtually every aspect of traditional Tantric Buddhism schemes, of (1) outer (Buddha, Dharma, Sangha), inner (lama, tutelary or meditational deity, protector) and secret (the three kayās) forms of the Three Jewels or the Three Refuges, as well as (2) three secret vajras: enlightened body, speech, and mind, where some of these categories or subcategories might overlap. The above categorisation of the images, the multitude of topics they evoke, various motifs and colours of Avalokiteśvara's images show how in the Tibetan religious vision, the versatility ascribed to Bodhisattvas can be depicted.

\section{Bibliography}

SH - Dpal ldan shangs pa bka’ brgyud kyi gser chos rnam lnga. 1982. Karma rang byung kun khyab, ed. Sonada: Kunkhyab Chuling.

Beer, Robert. 2004. The Encyclopedia of Tibetan Symbols and Motifs. London: Serindia Publications.

Bhasmajābala Upaniṣad, accessed: January 10, 2020, http://www.gayathrimanthra.com/ contents/documents/Vedic-related/bhasma.pdf.

Bla ma khyung po rnal 'byor gyi rnam thar zur tsam. 1982. In SH, vol. ka (I), 59-144.

Dpal ldan shangs pa bka' brgyud kyi do ha rdo rje'i tshig rkang dang mgur dbyangs phyogs gcig tu bsgrigs pa thos pa don ldan byin rlabs rgya mtsho. 1982. In SH, vol. ca (V), 251-288.

Dpal nag po chen po'i rgyud le’u brgyad pa. 1982. In SH, vol. da (XI), 1-152. 
Dpal ye shes kyi mgon po phyag drug pa'i chos skor byung tshul dngos grub bdud rtsi’i char 'bebs. 1982. In SH, vol. ka (I), 717-749.

Grela, Joanna. 2005. Mahakala. Sześcioręki strażnik w buddyzmie tybetańskim. Kraków: Universitas.

Gzhon nu dpal. 1996. The Blue Annals. Translated by George N. Roerich. Delhi: Motilal Banarsidass.

Karma ngag dbang yon tan rgya mtsho (alias Kongs sprul blo gros mtha' yas). 1982. Dpal ldan shangs pa bka' brgyud kyi ngo mtshar rin chen brgyud pa'i rnam thar la gsol ba 'deb pa u dumba ra'i phreng ba. In SH, vol. ca (V), 116-126.

Kongs sprul blo gros mtha' yas. 1982. Dpal myur mdzad ye shes kyi mgon po'i gtor chog rgyas pa'i kha skong dmigs rim dang bcas pa gsal bar bkod pa las bzhi lhun grub. In SH, vol. nga (IV), 273-339.

Mahābhārata, accessed September 16, 2021, https://www.sacred-texts.com/hin/m10/index.htm..

Maxwell, Thomas S. 1997. The Gods in Asia. Image, Text, and Meaning. Delhi: Oxford University Press.

Mgon dkar yid bzhin nor bu'i bskang gsol 'dod rgu'i char bebs. 1982. In SH, vol. nga (IV), 395-444.

Myur mdzad ye shes kyi mgon po phyag drug pa'i bsnyen sgrub las gsum gyi man ngag zhal shes dang bcas pa phrin las lhun grub. 1982. In SH, vol. cha (VI), 397-435.

Namkai Norbu. 1989. "Preface." In Jam dbyangs mkhyen brtse'i dbang po. The Secret Book of Simhamukha. The Excellent Vase of Precious Jewels. Translated by John Myrdhin Reynolds. Tsegyalgar: Vidyadhara Publications.

Panofsky, Erwin. 1955. "Iconography and Iconology: An Introduction to the Study of Renaissance Art." In Erwin Panofsky, Meaning in the Visual Arts, 26-54. Garden City, NY: Doubleday.

Tāranātha. 1982. Dpal ye shes kyi mgon po phyag drug pa'i chos skor byung tshul dngos grub bdud rtsi'i char 'bebs. In SH, vol. ka (I), 717-749.

Tcheuky Sengué. 2002. Petite encyclopédie des divinités et symboles du bouddhisme tibétain. Saint-Cannat: Claire Lumière.

\section{Internet sources of the photos:}

Four Deities in one Mandala, accessed February 17, 2020, https://paldenshangpa.org/combined-accomplishment-of-the-four-deities-lha-chi-dril-droup/4-deities-2/.

Green Six-Armed Mahākalā, accessed February 28, 2020, https://www.amazon.co.uk/Tibetan-Buddhist-Six-Armed-Shadbhuja-Mahakala/dp/B00MPGN3JW.

White Six-Armed Mahākalā, accessed February 17, 2020, https://www.shangpafoundation. org/library/artifact-page/white-protector/. 